\title{
A redescription of Pseudocharopinus pteromylaei Raibaut et Essafi, 1979 (Siphonostomatoida: Lernaeopodidae) collected from the South African east coast
}

\author{
Susan M. Dippenaar
}

Department of Biodiversity, University of Limpopo, Private Bag X1106, Sovenga 0727, South Africa

\begin{abstract}
Pseudocharopinus Kabata, 1964 is one of the 48 genera comprising the Lernaeopodidae (Copepoda, Siphonostomatoida). Currently there are 11 accepted species contained in Pseudocharopinus. Pseudocharopinus pteromylaei Raibaut et Essafi, 1979 infects the spiracles and gill filaments of Pteromylaeus bovinus (Geoffroy St. Hilaire) and is most similar in general appearance to P. pteroplateae (Yamaguti et Yamasu, 1959) from which it clearly differs in the size and dimensions of the dorsal shield and the posterior processes. Additional features of the antenna and the maxilliped of P. pteromylaei, not previously illustrated, are discussed and illustrated while more detailed illustrations of other appendages are provided. This is the first report of the occurrence of a Pseudocharopinus species from the west Indian Ocean and the first report of $P$. pteromylaei off the east coast of South Africa.
\end{abstract}

Keywords: Pseudocharopinus, meso-parasitic copepod, bull ray, South Africa

The Lernaeopodidae Milne Edwards, 1840 contains 48 genera (Boxshall and Halsey 2004) including Cauloxenus Cope, 1872 whose validity was considered to be uncertain (Kabata 1979). Lernaeopodids are found attached to virtually all external body surfaces of their teleost and chondrichthyan hosts (Benz et al. 2000), with members of six of these genera found in fresh water, whereas all others are marine (Kabata 1979). In general, all lernaeopodids exhibit a high degree of host and attachment site specificity (Kabata 1979).

Females of species of Pseudocharopinus Kabata, 1964 are distinguished from those of Charopinus Krøyer, 1863 by the following characteristics (Kabata 1964, 1979): members of Pseudocharopinus have a well-developed dorsal shield with the head distinctly delimited, the bases of the antennae are heavily sclerotized, the maxillipeds are close to the mouth cone and well developed, and the bulla's collar (see Benkirane et al. 1999) is circular or plano-convex and always sclerotized in adult females.

The Pseudocharopinus female is a representative of Kabata's (1979, fig. 61) type-C structural plan and has the following characteristics (Kabata 1964, 1979): cephalothorax elongate, cylindrical, about $2 / 3$ the length of the trunk; head distinctly delimited from the rest of the cephalothorax, definite and well-developed dorsal shield present; trunk dorsoventrally flattened, longer than broad, anteriorly distinctly narrower, forming a "neck"; antennule indistinctly 3 or 4-segmented, with well-developed apical armature; antenna prehensile; mandible with three secondary teeth; maxillule with lateral exopod (outer lobe/palp according to Boxshall 1990) and endopod (inner lobe/endite according to Boxshall 1990) with three terminal papillae; maxillae longer or slightly shorter than cephalothorax, united at the tips; bulla of usual lernaeopodid type, characterized by a short manubrium (Benkirane et al. 1999); maxillipeds ventrally on the cephalothorax, well developed and close to the mouth-cone; two posterior processes (uropods), sometimes vestigial, dorsal to egg sacs.

There are currently 11 species of Pseudocharopinus (see Boxshall and Halsey 2004, Boxshall 2011). These include P. bicaudatus (Krøyer, 1837); P. concavus (Wilson, 1913); P. dasyaticus (Rangnekar, 1957); P. dentatus (Wilson, 1912); P. kabatai (Pillai, 1962); P. malleus (Rudolphi in von Nordmann, 1832); P. markewitschi (Gusev, 1951); P. narcinae (Pillai, 1962); P. pastinacae (Beneden, 1851); P. pteromylaei Raibaut et Essafi, 1979; and P. squali (Wilson, 1944). However, these include P. pastinacae that was synonymized with $P$. malleus (see Raibaut and Maamouri 1975, Walter 2011) and exclude P. pteroplateae (Yamaguti et Yamasu, 1959), which should be included according to Kabata (1979), and which clearly lacks the pair of long ventrolateral processes on the trunk (see fig. 287 in Yamaguti and Yamasu 1959), characteristic of Brianella Cuvier, 1830 - Kabata (1979). Additionally, Kabata (1979) proposed using P. pillaii for P. dasyaticus (Pillai, 1962) due to the transfer of Clavellopsis dasyaticus Rangnekar, 1957 and Charopinus dasyaticus to the 
genus Pseudocharopinus. Pillai (1985) was not aware of this as he suggested the use of Pseudocharopinus kabatai. However, he did correct the mistake in favour of the use of $P$. pillaii in the addendum (see Pillai 1985 - page 878). It is therefore evident that the name $P$. kabatai should be discarded in favour of $P$. pillaii.

During an examination of the collected $P$. pteromylaei specimens it became clear that there were additional features and more detail that were not illustrated in the original description of $P$. pteromylaei by Raibaut and Essafi (1979). Such detail may become vital in future to attempt an estimation of relationships among species and genera and therefore a redescription is warranted.

\section{MATERIALS AND METHODS}

Copepod samples were collected from Pteromylaeus bovinus (Geoffroy St. Hilaire) caught in the nets of the KwaZulu-Natal Sharks Board set along the east coast of South Africa. Collected specimens were fixed and preserved in $70 \%$ ethanol and examined, using the wooden slide technique (Humes and Gooding 1964), after being cleared in lactic acid with a small amount of dissolved lignin pink. Drawings were made with the aid of drawing tubes and measurements were done with an ocular micrometer. Terminology used conforms to that of Kabata (1979), Boxshall (1990) and Huys and Boxshall (1991), whereas host nomenclature used is according to Compagno (1999) and Froese and Pauly (2012).

\section{RESULTS}

Pseudocharopinus pteromylaei Raibaut et Essafi, 1979

Figs. 1-2

Female (Figs. 1, 2): Cephalothorax (Figs. 1A, 2A) cylindrical, about as long as trunk, anteriorly expanded into large head (comprising more than 1/2 of cephalothorax), roughly in line with long axis of cephalothorax; head covered by elongate dorsal shield with distinct margins. Trunk (Figs. 1A, 2A) quadrangular, narrowing anteriorly; posterodorsal and posteroventral corners rounded, posteroventrally with central tubercle bearing genital orifices (Fig. 2A). Total length (without egg sacs) about $10.1 \mathrm{~mm}$; cephalothorax length $3.5 \mathrm{~mm}$, width $1.3 \mathrm{~mm}$; maxillae length $3.6 \mathrm{~mm}$; trunk length $4 \mathrm{~mm}$; posterior processes $2.6 \mathrm{~mm}$; egg sacs $7.0 \mathrm{~mm}$.

Antennule (Fig. 2E) three-segmented; basal segment much broader than distal two segments with long, slender whip near apex; second segment not distinctly separated from last segment, with solus on lateral wall; distal segment with apical armature consisting of three setae and three tubercles arranged in standard pattern (see fig. 1615 in Kabata 1979). Antenna (Fig. 2G) biramous, exopod one-segmented, bulbous, denticulated, overlapping endopod; endopod (Fig. 2H) two-segmented, proximal segment with ventral patch of denticles; distal segment

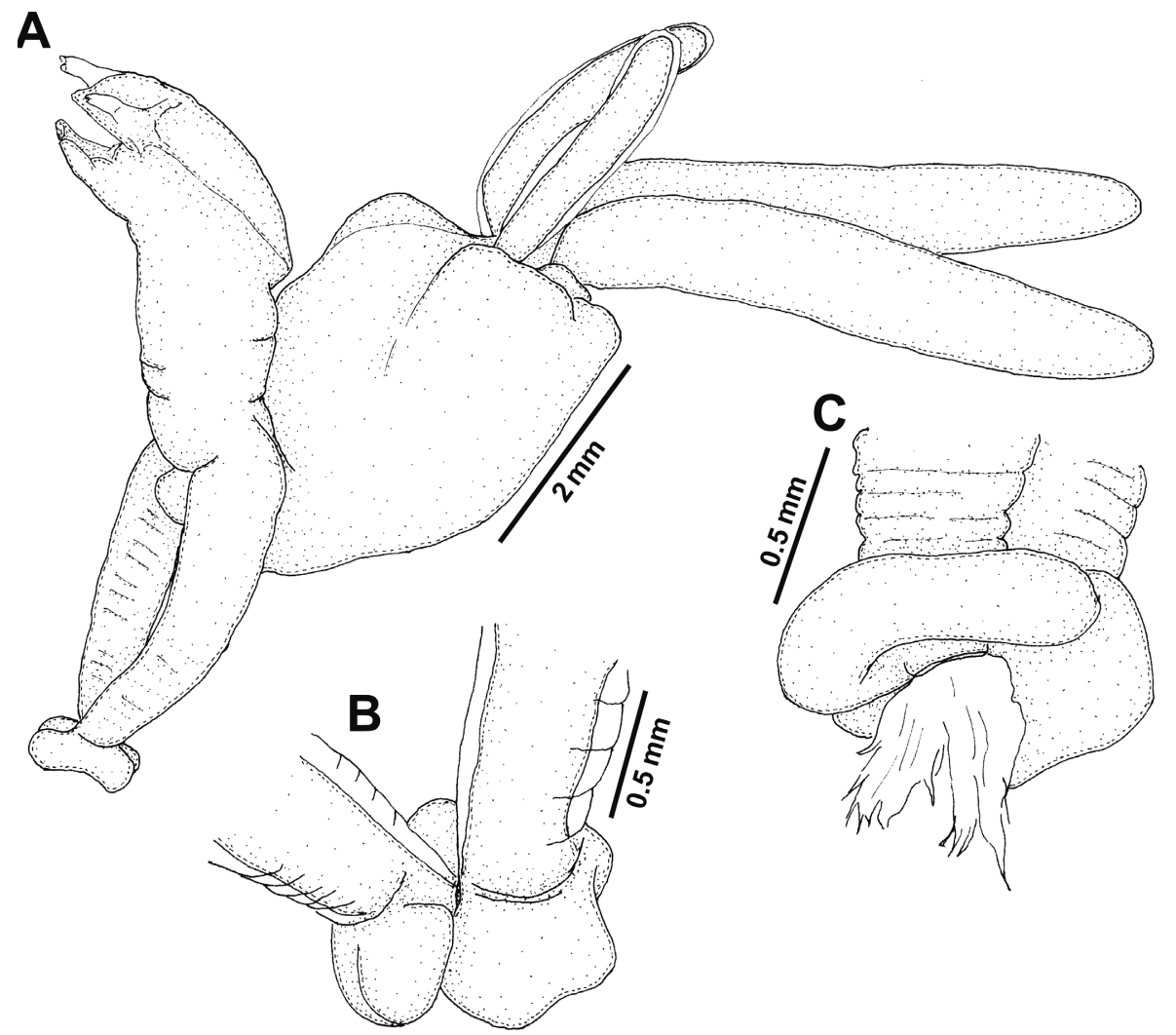

Fig. 1. Pseudocharopinus pteromylaei Raibaut et Essafi, 1979, adult female; A - habitus, dorsolateral view; B - tips of maxillae with circular collar and bulla, dorsal; $\mathbf{C}$ - tips of maxillae with circular collar, anchor of bulla and attached host tissue, ventrolateral. 

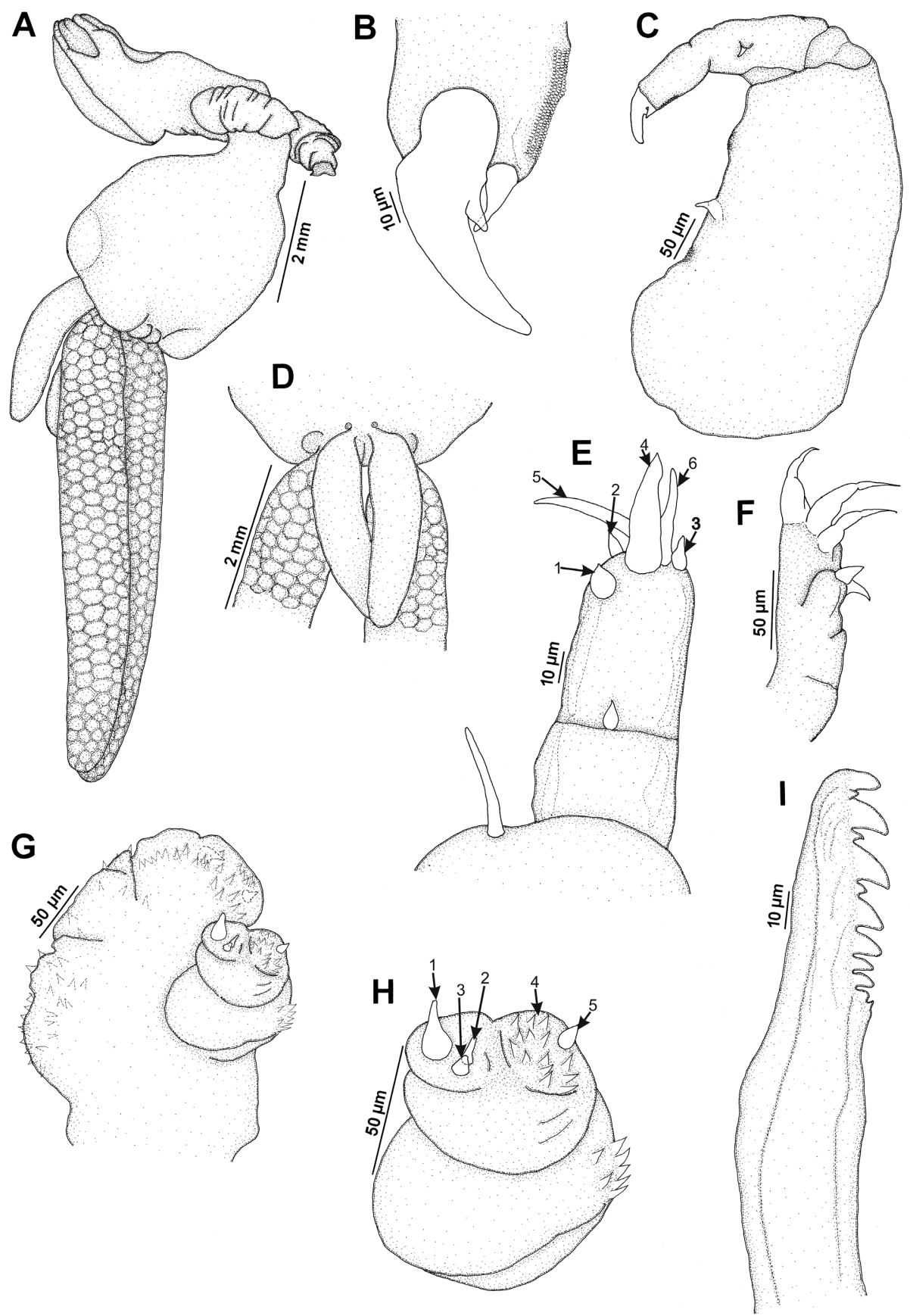

Fig. 2. Pseudocharopinus pteromylaei Raibaut et Essafi, 1979, female; A - general habitus, ventrolateral view; B - maxilliped, tip; C - maxilliped; D - perianal region, dorsal view; $\mathbf{E}$ - antennule, 1-6 according to Kabata (1979 - Fig. 1615); F - maxillule; G - antenna; H - antenna, endopod, 1-5 according to Kabata (1979 - Fig. 1616); I - mandible, tip.

with relatively small, but distinct hook 1 ; spiniform seta 2 ; prominent tubercle 3; inflated ventral wall 4 , with fairly large but sparse denticles; and process 5, arising from wall of 4 (see fig. 1616 in Kabata 1979). Mandible (Fig. 2I) with dental formula P1, S1, P1, S1, P1, S1, B5; two distalmost teeth of basal series about same size as primary teeth, three more proximal teeth much smaller. Maxillule (Fig. 2F) biramous, exopod $=$ outer lobe/palp with two small naked setae at apex, endopod = inner lobe/ endite with three truncated naked setae at apex. Maxilla (Figs. 1A, 2A) almost same length as trunk, transversely wrinkled, united only at small bulla; tips inflated to form small, circular collar around manubrium of bulla (Fig. 1B, C). Maxilliped (Fig. 2B, C) with distally tapering corpus, reaching tip of mouth cone (Figs. 1A, 2A); myxa with one short naked seta, arising from small swelling at about midlength and two denticulated pads, one near base of corpus and another close to base of subchela; subchela 
slender, about $1 / 2$ length of corpus, with short basal seta, short distal conical barb, and distal part on inner margin denticulated; claw (Fig. 2B) short, mildly curved, blunt with one secondary tooth proximally on inner margin. Posterior processes (Figs. 1A, 2A, D) longer than 1/2 trunk length, cylindrical with rounded tips, somewhat curving, dorsal to egg sacs. Egg sacs (Figs. 1A, 2A) about as long as total length, egg arrangement multiseriate.

Ho st: Pteromylaeus bovinus (Geoffroy St. Hilaire) (Elasmobranchii, Myliobatidae).

Site of infection: Spiracle and gill filaments.

L o c a lity: Durban, $29.51^{\circ} \mathrm{S} 31.00^{\circ} \mathrm{E}$, South Africa.

Material examined: One adult $o$ (without maxillae tips and bulla) from a host caught in Nov. 1997; one adult + (without maxillae tips and bulla) from a host caught in Oct. 1998 and one adult $q$ (complete) from a host caught in January 2012.

Remarks. In comparing the collected specimens with literature descriptions of all the Pseudocharopinus species (Wilson 1913, 1944, Markewich 1956, Rangnekar 1957, Yamaguti and Yamasu 1959, Pillai 1962, 1985, Kabata 1964, 1979, Kirtisinghe 1964, Raibaut and Maamouri 1975, Raibaut and Essafi 1979), the shape of the trunk of $P$. pteromylaei roughly resembles those of $P$. bicaudatus ('roughly circular' - Kabata 1964, 'trunk short' - Markewitch 1956, and almost as long as cephalothorax - Kabata 1979), P. dasyaticus (shorter than cephalothorax and 'pyriform' - Rangnekar 1957) and P. pteroplateae (shorter than cephalothorax and 'oval' - Yamaguti and Yamasu 1959), with all the others having more elongated trunks, mostly longer than the cephalothorax. However, of these three species the shape and size of the posterior processes of $P$. pteromylaei only resembles those of P. bicaudatus ('well-developed' - Kabata 1964, digitate, 'thick' Markewitch 1956 and about 2/3 the length of the trunk - Kabata 1979) and P. pteroplateae ('subcylindrical' and about 1/3 of trunk length - Yamaguti and Yamasu 1959) with those of $P$. dasyaticus small (Rangnekar 1957).

Pseudocharopinus pteromylaei can easily be distinguished from P. bicaudatus by the shape of the body. Pseudocharopinus bicaudatus has a much shorter cephalothorax (see Kabata 1964 - Fig. 38 and Kabata 1979 Fig. 1610) and shorter maxillae with the dorsal flexion of the anterior part of the body occurring posterior to the maxillae. Pseudocharopinus pteromylaei has a longer cephalothorax (see Figs. 1A, 2A and Raibaut and Essafi 1979 - Fig. 14), longer maxillae and the dorsal flexion takes place at the origin of the maxillae. The distinction between P. pteromylaei and P. pteroplateae is less obvious, but there are clear differences in body dimensions, i.e. the dorsal shield of P. pteroplateae is just more than
$1 \mathrm{~mm}$ long and covers less than half of the cephalothorax (see Yamaguti and Yamasu 1959), whereas the dorsal shield in P. pteromylaei is longer than $2 \mathrm{~mm}$ and covers more than half of the cephalothorax (Figs. 1A, 2A; see also fig. 14 in Raibaut and Essafi 1979). Additionally, the posterior processes of $P$. pteroplateae are less than $1 \mathrm{~mm}$ long (see Yamaguti and Yamasu 1959), whereas those of P. pteromylaei are more than $2 \mathrm{~mm}$ long (Figs. 1A, 2A; see also fig. 14 in Raibaut and Essafi 1979). There are also differences in the structure and armature of some of the appendages but these may be due to oversight and are thus not discussed.

Differences are observed in the armature of the appendages of the studied specimens and those of P. pteromylaei (see Raibaut and Essafi 1979), i.e. the armature of the antenna with the prominent tubercle 3 and unarmed process 5 , arising from the wall of 4 , are not indicated (see fig. 19 in Raibaut and Essafi 1979) and the myxa of the maxilliped of Raibaut and Essafi's (1979) P. pteromylaei has one extra denticulated pad closer to the base of the subchela (see fig. 22 in Raibaut and Essafi 1979), while the secondary tooth proximally on the inner margin of the claw is present, but smaller and more distal (see fig. 23 in Raibaut and Essafi 1979) than in the present studied specimens (Fig. 2G, H).

Pseudocharopinus species apparently exhibit variable degrees of host specificity with $P$. pteromylaei, $P$. concavus, P. pteroplateae and P. squali only reported from a single host species (Wilson 1913, 1944, Yamaguti and Yamasu 1959, Raibaut and Essafi 1979), whereas the other species were reported from two to six host species. However, the single host species reports may also be due to fewer reports and the relative scarcity of Pseudocharopinus species if considering the very low prevalence of 6.4\% exhibited by P. pteromylaei in South African waters.

Currently the only species reported from the Indian Ocean are $P$. dasyaticus, $P$. pillaii and $P$. narcinae (Pillai 1962, 1985, Kabata 1979), whereas P. pteromylaei was reported from the Mediterranean (Raibaut and Essafi 1979). Thus, this is the first report of a Pseudocharopinus species from the western Indian Ocean and also the first report of P. pteromylaei off the coast of South Africa.

Acknowledgements. I would like to thank the KwaZulu-Natal Sharks Board and the Department of Biodiversity (University of Limpopo (UL)) for field and laboratory support and the Department of Research Development and Administration (UL) for financial support. Furthermore, I also want to express my appreciation towards Ms B.P. Jordaan for assistance during field trips and my postgraduate students who lately assisted in the collection of material. Acknowledgement also goes towards G.W. Benz, P.A.S. Olivier, G. Boxshall and D. Tang for advice given during writing the manuscript. 
Benkirane O., Coste F., Raibaut A. 1999: On the morphological variability of the attachment organ of Lernaeopodidae (Copepoda: Siphonostomatoida). Folia Parasitol. 46: 67-75.

Benz G.W., Kabata Z., Bullard S.A. 2000: Margolisius abditus n. gen., n. sp. (Copepoda: Lernaeopodidae) from gill lamellae of a remora (Remora remora) collected in the Gulf of California. J. Parasitol. 86: 241-244.

Boxshall G. 1990: The skeletomusculature of siphonostomatoid copepods, with an analysis of adaptive radiation in structure of the oral cone. Phil. Trans. R. Soc. Lond. B 328: 167-212.

Boxshall G. 2011: Pseudocharopinus Kabata, 1964. In: T.C. Walter and G. Boxshall (Eds.), World Copepoda database, http:// www.marinespecies.org/copepoda, version 2012-03-27.

Boxshall G.A., Halsey S.H. 2004: An Introduction to Copepod Diversity. The Ray Society, London, 966 pp.

Compagno L.J.V. 1999: An overview of chondrichthyan systematics and biodiversity in southern Africa. Trans. R. Soc. S. Afr. 54: 75-120.

Froese R., Pauly D. (Eds.) 2012: FishBase. World Wide Web electronic publication, www.fishbase.org, version 02/2012.

Humes A.G., Gooding R.U. 1964: A method for studying the external anatomy of copepods. Crustaceana 6: 238-240.

Huys R., Boxshall G.A. 1991: Copepod Evolution. The Ray Society, London, $468 \mathrm{pp}$.

Kabata Z. 1964: Revision of the genus Charopinus Krøyer, 1863 (Copepoda: Lernaeopodidae). Vidensk. Meddr. Dansk. Naturh. Foren. 127: 85-112.

Kabata Z. 1979: Parasitic Copepoda of British Fishes. The Ray Society, London, $468 \mathrm{pp}$.
Kirtisinghe P. 1964: A review of the parasitic copepods of fish recorded from Ceylon with descriptions of additional forms. Bull. Fish. Res. Station, Ceylon 17: 45-132.

Markewitch A.P. 1956: [Parasitic Copepods on the Fishes of the USSR.] Izd. Akad. Nauk Ukr. SSR, Kiev, 259 pp. (In Russian.)

Pillai N.K. 1962: Copepods parasitic on south Indian fishes. Families Lernaeopodidae and Naobranchidae. J. Mar. Biol. Ass. India 4: 58-94.

Pillai N.K. 1985: The Fauna of India: Copepod Parasites of Marine Fishes. Zoological Survey of India, Calcutta, 900 pp.

Raibaut A., Essafi K. 1979: Description de deux espèces nouvelles de copépodes parasites de sélaciens de Tunisie. Bull. Mus. Natl. Hist. Nat., Paris, 4ème Sér., 1: 435-443.

Raibaut A., Maamouri K. 1975: Remarques sur deux espèces de copépodes parasites de sélaciens de Tunisie. Bull. Mus. Natl. Hist. Nat., Paris, 3ème Sér., 320, Zool. 227: 1037-1047.

RANGNekAR M.P. 1957: Copepod parasites of the families Argulidae, Caligidae, Dichelestidae, and Lernaeopodidae. J. Univ. Bombay 26: 8-20.

Walter T.C. 2011: Brachiella pastinacae Beneden, 1851. In: T.C. Walter and G. Boxshall (Eds.), World Copepoda database, http://www.marinespecies.org/copepoda, version 2012-03-26.

WiLson C.B. 1913: Crustacean parasites of West Indian fishes and land crabs, with descriptions of new genera and species. Proc. U. S. Natl. Mus. 44: 189-277.

Wilson C.B. 1944: Parasitic copepods in the United States National Museum. Proc. U. S. Natl. Mus. 94: 529-582.

Yamaguti S., Yamasu T. 1959: Parasitic copepods from fishes of Japan with descriptions of 26 new species and remarks on two known species. Biol. J. Okayama Univ. 5: 89-165.

Accepted 7 June 2012 